\title{
PENGARUH GENDER, PENGALAMAN AUDITOR, KOMPLEKSITAS TUGAS, TEKANAN KETAATAN, KEMAMPUAN KERJA DAN PENGETAHUAN AUDITOR TERHADAP AUDIT JUDGEMENT
}

\author{
Reni Yendrawati, Dheane Kurnia Mukti \\ Fakultas ekonomi Universitas Islam Indonesia \\ Email: reni.yendrawati@uii.ac.id, dheane kurnia@yahoo.com
}

\begin{abstract}
This research was aimed to examine and to obtain empirical evidents on effects of gender, auditor experience, task complexity, obedience pressure, ability and knowledge toward audit judgement taken by auditor. This research was carried out at the DIY BPK representative. Collecting data was conducted by questionare distributed as much 40 , however only 35 questionaires replayed, that gender didn't significanly affect audit judgement, experience, task complexity, ability and knowledge significanly positive affect audit judgement, and obidience pressure significanly negaative effect audit judgement.
\end{abstract}

Keywords: gender, auditor's experience, task complexity, obidience pressure, ability, knowledge, audit judgement.

\section{PENDAHULUAN}

Terjadinya kasus kegagalan audit belakangan ini, telah menimbulkan krisis kepercayaan masyarakat akibat ketidakmampuan profesi akuntansi dalam mengaudit laporan keuangan. Sehingga, masyarakat menuntut sektor publik khususnya pemerintah untuk melaksanakan akuntabilitas pengelolaan keuangan sebagai bentuk terwujudnya praktik good governance. Menurut Bastian (2007) audit sektor publik merupakan audit yang dilakukan pada organisasi pemerintahan yang bersifat nirlaba, seperti sektor pemerintahan daerah (pemda), BUMN, BUMD dan instansi lain yang berkaitan dengan pengelolaan aktiva/kekayaan negara.

Pengguna laporan keuangan mengharapkan adanya laporan keuangan yang dapat dipercaya, lengkap dan benar sehingga dapat dijadikan dasar untuk pengambilan keputusan. Seorang auditor dalam melakukan tugasnya membuat audit judgement dipengaruhi oleh banyak faktor, baik bersifat teknis ataupun non teknis.

Gender diduga menjadi salah satu faktor level individu yang turut mempengaruhi audit judgement seiring dengan terjadinya perubahan pada kompleksitas tugas dan pengaruh tingkat kepatuhan terhadap etika. Tekanan atasan pada konsekuensi yang memerlukan biaya juga berpengaruh, seperti tuntutan hukum, hilangnya profesionalisme, dan hilangnya kepercayaan publik dan kredibilitas sosial. Hal tersebut mengindikasikan adanya pengaruh dari tekanan atasan pada judgement yang diambil auditor. Pengaruh sejumlah faktor terhadap kompleksitas tugas juga bersifat penting karena kecenderungan bahwa tugas melakukan audit adalah tugas yang banyak menghadapi persoalan yang kompleks. Ada tiga alasan yang cukup mendasar mengapa pengujian terhadap kompleksitas tugas untuk 
sebuah situasi audit perlu dilakukan. Pertama, kompleksitas tugas ini diduga berpengaruh signifikan terhadap kinerja seorang auditor. Kedua, sarana dan teknik pembuatan keputusan dan latihan tertentu diduga telah dikondisikan sedemikian rupa ketika para peneliti memahami keganjilan pada kompleksitas tugas audit. Ketiga,pemahaman terhadap kompleksitas dari sebuah tugas dapat membantu tim manajemen audit perusahaan menemukan solusi terbaik bagi staf audit dan tugas audit.

Mardisar dan Sari (2007) rmengatakan bahwa kinerja seorang auditor dapat diukur dengan beberapa unsur antara lain kemampuan (ability), pengetahuan (knowledge), dan pengalaman (experience). Kemampuan merupakan salah satu faktor utama yang harus dimiliki seorang auditor, dengan kemampuan yang dimilikinya memungkinkan tugas-tugas pemeriksaan yang dijalankan dapat diselesaikan secara baik dengan hasil yang maksimal. Pengalaman dan pengetahuan merupakan faktor penting yang berkaitan dengan pemberian pendapat audit. Karena pengalaman dan pengetahuan dapat mempengaruhi kemampuan prediksi dan deteksi auditor terhadap kecurangan sehingga dapat mempengaruhi judgement yang diambil auditor.

\section{PERUMUSAN MASALAH}

Berdasarkan latar belakang diatas, maka yang menjadi permasalahan dalam penelitian ini adalah:

'Bagaimana pengaruh gender, pengalaman auditor, kompleksitas tugas, tekanan ketaatan, kemampuan kerja dan pengetahuan terhadap judgement yang diambil oleh auditor?'

\section{Tujuan Penelitian}

Tujuan dari penelitian ini adalah untuk menganalisis pengaruh gender, pengalaman auditor, kompleksitas tugas, tekanan ketaatan, kemampuan kerja dan pengetahuan auditor terhadap audit judgement.

\section{KAJIAN PUSTAKA DAN RUMUSAN HIPOTESIS}

\section{Audit Judgement}

Audit judgement sebagai kebijakan auditor dalam menentukan pendapat mengenai hasil auditnya yang mengacu pada pembentukan suatu gagasan, pendapat atau perkiraan tentang suatu obyek, peristiwa, status atau jenis peristiwa lain. Cara pandang auditor dalam menanggapi informasi berhubungan dengan tanggungjawab dan risiko audit yang akan dihadapi oleh auditor sehubungan dengan judgement yang dibuatnya.

\section{Gender}

Kata "gender" berasal dari bahasa inggris, gender, berarti jenis kelamin. Dalam Webster's New World, gender diartikan sebagai perbedaan yang tampak antara lakilaki dan perempuan dilihat dari segi nilai dan tingkah laku. Sedangkan dalam Women's Studies Encyclopedia dijelaskan bahwa gender adalah suatu konsep kultural yang berupaya membuat pembedaan (distinction) dalam hal peran, perilaku, mentalitas dan karakteristik emosional antara laki-laki dan perempuan yang berkembang dalam masyarakat.

\section{Pengalaman Auditor}

Pengalaman sebagai salah satu variabel yang banyak digunakan dalam berbagai penelitian sehubungan dengan judgement yang diambil oleh auditor. Penggunaan pengalaman didasarkan pada asumsi bahwa tugas yang dilakukan secara berulang-ulang memberikan peluang untuk belajar melakukannya dengan yang terbaik. Pengalaman adalah keseluruhan pelajaran yang dipetik oleh seseorang dari peristiwaperistiwa yang dialami dalam perjalanan hidupnya.

Akram, Inapty, Sukriah (2009), menyatakan bahwa seorang karyawan yang memiliki pengalaman kerja yang tinggi akan memiliki keunggulan dalam beberapa hal diantaranya: 1) mendeteksi kesalahan, 2) memahami kesalahan, dan 3) mencari penyebab 
munculnya kesalahan.Herliansyah dan llyas (2006), menemukan bahwa pengalaman audit yang dipunyai auditor ikut berperan dalam menentukan pertimbangan (judgement) yang diambil sehingga dapat meningkatkan kualitas audit.

\section{Kompleksitas Tugas}

Auditor selalu dihadapkan dengan tugastugas yang banyak, berbeda-beda dan saling terkait satu sama lain. Jamilah dkk (2007) kompleksitas adalah sulitnya suatu tugas yang disebabkan oleh terbatasnya kapabilitas, dan daya ingat serta kemampuan untuk mengintegrasikan masalah yang dimiliki oleh seorang pembuat keputusan. Tingkat kesulitan tugas dan struktur tugas merupakan dua aspek penyusun dari kompleksitas tugas. Tingkat sulitnya tugas selalu dikaitkan dengan banyaknya informasi tentang tugas tersebut, sementara struktur adalah terkait dengan kejelasan informasi (information clarity).

\section{Tekanan Ketaatan}

Tekanan ketaatan adalah jenis tekanan pengaruh sosial yang dihasilkan ketika individu dengan perintah langsung dari perilaku individu lain. Dalam hal ini tekanan ketaatan diartikan sebagai tekanan yang diterima oleh auditor junior dari auditor senior atau atasan dan entitas yang diperiksa untuk melakukan tindakan yang menyimpang dari standar profesionalisme.

\section{Kemampuan Kerja}

Kemampuan merupakan unsur penting yang harus dimiliki oleh seorang auditor independen untuk bekerja sebagai tenaga profesional. Seorang karyawan yang tidak memiliki kemampuan untuk menganalisis persoalan mungkin sekali tidak akan berusaha sungguh-sungguh untuk memecahkannya. Kemampuan atau (ability) merujuk ke suatu kapasitas individu untuk mengerjakan berbagai tugas dalam suatu pekerjaan.

\section{Pengetahuan Auditor}

Herawaty dan Yulius (2009), seseorang yang melakukan pekerjaan sesuai dengan pengetahuan yang dimilikinya akan memberikan hasil yang lebih baik daripada mereka yang tidak memiliki pengetahuan yang cukup memadai akan tugasnya. Auditor harus telah menjalani pendidikan dan pelatihan teknis yang cukup dalam praktik akuntansi dan teknik auditing sehingga mampu menjalankan tugasnya dengan baik dan tepat, Kushasyandita dan Januarti (2012).

\section{Perumusan Hipotesis}

\section{Pengaruh Gender terhadap judgement yang diambil auditor.}

Kaum wanita relatif lebih efisien dibandingkan kaum pria selagi mendapat akses informasi. Selain itu, kaum wanita juga memiliki daya ingat yang lebih tajam terhadap suatu informasi baru dibandingkan kaum pria dan demikian halnya kemampuan dalam mengolah informasi yang sedikit menjadi lebih tajam. Penelitian Praditaningrum dan Januarti (2011), menyatakan bahwa gender berpengaruh terhadap audit judgement.

Berdasarkan uraian di atas, maka dapat dirumuskan hipotesis sebagai berikut:

H1 : Gender berpengaruh terhadap judgement yang diambil oleh auditor.

\section{Pengaruh pengalaman auditor terhadap judgement yang diambil oleh auditor.}

Pengalaman mengarah kepada proses pembelajaran dan pertambahan potensi bertingkah laku dari pendidikan formal maupun nonformal atau bisa diartikan sebagai suatu proses peningkatan pola tingkah laku. Banyaknya pengalaman dalam bidang audit dapat membantu auditor dalam menyelesaikan tugas yang cenderung memiliki pola yang sama.

Berdasarkan uraian di atas, maka dapat dirumuskan hipotesis sebagai berikut:

H2 : Pengalaman auditor berpengaruh positif terhadap audit judgement yang diambil oleh auditor.

Pengaruh kompleksitas tugas terhadap audit judgement yang diambil oleh auditor. 
Berdasarkan teori motivasi $\mathrm{X}$ dan $\mathrm{Y}$, apabila dihadapkan pada suatu tugas dengan kompleksitas yang tinggi auditor akan cenderung termasuk dalam tipe $\mathrm{X}$. Auditor tersebut akan mengalami kesulitan dalam menyelesaikan tugasnya. Akibatnya auditor tidak mampu mengintegrasikan informasi menjadi suatu judgement yang baik. Teori penetapan tujuan juga menjelaskan bahwa auditor yang tidak mengetahui tujuan dan maksud dari tugasnya juga akan mengalami kesulitan ketika harus dihadapkan pada suatu tugas yang kompleks. Auditor tersebut tidak mengetahui sasaran apa yang harus dia capai dalam pelaksanaan tugasnya sehingga dapat mempengaruhi keakuratan dari judgement yang diambilnya.

Berdasarkan uraian di atas, maka dapat dirumuskan hipotesis sebagai berikut:

H3 : Kompleksitas tugas berpengaruh negatif terhadap judgement yang diambil oleh auditor.

\section{Pengaruh tekanan ketaatan terhadap judgement yang dimbil oleh auditor.}

Berdasarkan teori motivasi $\mathrm{X}$ dan $\mathrm{Y}$, seorang individu yang mendapat tekanan ketaatan dari atasan maupun entitas yang diperiksa akan cenderung termasuk dalam tipe $X$ dimana mereka akan mengambil jalan yang aman dan bersikap disfungsional. Mereka belum mampu bertindak independensi dan masih merasa takut sehingga memilih jalan yang tidak beresiko. Hal ini akan mengakibatkan auditor tidak mampu membuat judgement yang baik dan tepat. Dalam teori penentuan tujuan juga dijelaskan auditor yang tidak mengetahui dengan pasti tujuannya biasanya cenderung mudah berperilaku menyimpang dengan menuruti perintah dari atasan dan entitas yang diperiksa untuk berperilaku menyimpang dari standar etika dan profesional.

Dalam melaksanakan tugas audit, auditor secara terus menerus berhadapan dengan dilema etika yang melibatkan pilihan antara nilai-nilai yang bertentangan (Jamilah,dkk., 2007).
Berdasarkan uraian di atas, maka dapat dirumuskan hipotesis sebagai berikut:

H4 : Tekanan ketaatan berpengaruh negatif terhadap judgement yang diambil oleh auditor.

\section{Pengaruh Kemampuan kerja terhadap judgement yang diambil oleh auditor.}

Kemampuan Kerja adalah sifat (bawaan atau dipelajari) yang memungkinkan seseorang melakukan sesuatu yang bersifat mental atau fisik. Adanya kemampuan seorang auditor dituntut untuk memiliki kemampuan untuk melakukan judgement yang akan diambil oleh auditor, sehingga keputusan yang diambil bisa menjadi keputusan yang terbaik.

Berdasarkan uraian di atas, maka dapat dirumuskan hipotesis sebagai berikut:

H5 : Kemampuan kerja berpengaruh positif terhadap judgement yang diambil oleh auditor.

\section{Pengaruh pengetahuan Auditor terhadap judgement yang diambil oleh auditor.}

Fitriani dan Daljono (2012), tingkat pengetahuan yang dimiliki auditor merupakan hal yang sangat penting yang dapat mempengaruhi auditor dalam mengambil keputusan. Dengan tingkat pengetahuan yang tinggi yang dimiliki oleh seorang auditor, auditor tidak hanya akan bisa menyelesaikan sebuah pekerjaan audit secara efektif tetapi juga akan mempunyai pandangan yang lebih luas mengenai berbagai hal.

Berdasarkan teori motivasi berprestasi, auditor yang memiliki motivasi yang kuat akan terus berusaha untuk menambah pengetahuannya mendukung kinerjanya. Sehingga keahlian dan pengetahuan auditor akan selalu berkembang dan mendukung auditor untuk membuat judgement profesional.

Berdasarkan uraian di atas, maka dapat dirumuskan hipotesis sebagai berikut:

H6 : Pengetahuan Auditor berpengaruh positif terhadap judgement yang diambil oleh auditor. 


\section{METODE PENELITIAN}

\section{Populasi dan Penentuan Sampel Penelitian}

Populasi dalam penelitian ini adalah seluruh auditor yang bekerja di BPK perwakilan DIY. Metode Pengambilan sampel yang digunakan adalah convenience sampling. Sampel dalam penelitian ini adalah beberapa auditor yang bekerja pada Badan Pengawas Keuangan (BPK) yang berada di perwakilan Daerah Istimewa Yogyakarta.

\section{Jenis Data dan Sumber Data}

Sumber data yang akan digunakan dalam penelitian ini adalah data primer yang diperoleh langsung dari auditor yang bekerja di BPK perwakilan DIY melalui teknik pengumpulan data yaitu dengan kuesioner. Daftar pertanyaan yang ada dikuesioner diambil dari literatur yang pernah diujikan sebelumnya.

Dalam penelitian ini, data diambil dari anggapan responden atas pertanyaan yang ada di dalam kuesioner dan setiap responden dimintai pendapatnya mengenai pertanyaanpertanyaan yang ada. Penelitian ini dalam pengukurannya menggunakan skala interval pada masing-masing pengaruh responden.

\section{Metode Pengolahan dan Analisis Data}

Dalam penelitian ini menggunakan alat analisis data, yaitu statistik deskriptif, uji kualitas data, uji asumsi klasik dan uji hipotesis. Uji asumsi klasik yang harus dipenuhi adalah uji normalitas, uji multikolinearitas, dan uji heterokedastisitas. Pengujian hipotesis dapat dilihat dari hasil uji t dengan tingkat signifikansi $5 \%$. Model regresi linear berganda ditunjukkan oleh persamaan berikut ini:

$$
\begin{aligned}
& Y=a+b 1 X 1+b 2 X 2+b 3 X 3+b 4 X 4+ \\
& \text { b5 } X 5+b 6 X 6+e \\
& \text { Keterangan: } \\
& Y=\text { audit judgement } \\
& a=\text { konstanta } \\
& \text { b1, b2 = koefisien regresi untuk X1,X2, X3, }
\end{aligned}
$$

$$
\mathrm{X} 4, \mathrm{X} 5 \text { dan X6 }
$$

$\mathrm{X} 1$ = gender

$\mathrm{X} 2$ = pengalaman auditor

$\mathrm{X} 3=$ kompleksitas tugas

X4 = tekanan ketaatan

$\mathrm{X} 5$ = kemampuan kerja

\begin{tabular}{|c|c|c|c|c|c|c|c|c|}
\hline \multicolumn{9}{|c|}{ Coefficients ${ }^{\mathrm{a}}$} \\
\hline \multirow{2}{*}{\multicolumn{2}{|c|}{ Model }} & \multicolumn{2}{|c|}{$\begin{array}{l}\text { Unstandardized } \\
\text { Coeff icients }\end{array}$} & \multirow{2}{*}{$\begin{array}{c}\text { Standardized } \\
\text { Coeff icients } \\
\text { Beta }\end{array}$} & \multirow[b]{2}{*}{$t$} & \multirow[b]{2}{*}{ Sig. } & \multicolumn{2}{|c|}{ Collinearity Statistics } \\
\hline & & B & Std. Error & & & & Tolerance & VIF \\
\hline \multirow[t]{7}{*}{1} & (Constant) & $-1,632$ & 1,040 & & $-1,568$ & ,128 & & \\
\hline & Gender & ,261 & ,201 & , 168 & 1,298 & 205 & ,801 & 1,249 \\
\hline & $\mathrm{PaG}$ & ,427 & ,205 & ,288 & 2,080 & ,047 & ,702 & 1,424 \\
\hline & KT & 1,234 & ,409 &, 527 & 3,019 & ,005 & ,441 & 2,268 \\
\hline & TK &,- 568 & 241 &,- 288 & $-2,358$ & ,026 & 902 & 1,109 \\
\hline & KK & 1,522 & ,572 &, 599 & 2,661 & ,013 & ,265 & 3,775 \\
\hline & PA & 1,851 & ,425 & ,784 & 4,354 & ,000 & ,414 & 2,413 \\
\hline
\end{tabular}

$\mathrm{X} 6=$ pengetahuan auditor

$\mathrm{e}=$ error term

\section{ANALISIS DAN PEMBAHASAN}

Berikut ini adalah tabel hasil uji hipotesis:

Tabel 1

Hasil Uji Hipotesis

a. Dependent Variable: AJ

Berdasarkan tabel diatas diperoleh persamaan regresi berganda:

$Y=-1,632+0,261 X_{1}+0,427 X_{2}+1,234 X_{3}-0,568 X_{4}+1,522 X_{5}+1,851 X_{6}$ 
Hasil olah data untuk variabel gender diperoleh nilai probabilitas-statistik 0,205 dan diperoleh nilai koefisien regresi $=0,261$, maka dapat disimpulkan bahwa variabel gender tidak berpengaruh secara signifikan terhadap audit judgement. Hal ini dapat diartikan, jika jumlah laki-laki atau perempuan meningkat maka audit judgement akan tetap atau konstan. Dengan demikian berarti hipotesis $\mathrm{H} 1$ tidak terbukti dengan penelitian yang dilakukan oleh Praditaningrum dan Januarti (2011), hal ini dapat disebabkan karena antara laki-laki dan perempuan dalam membuat audit judgement memiliki kemampuan yang sama dalam mengolah informasi maupun data yang ada. Hasil penelitian ini didukung dengan penelitian yang dilakukan oleh Jamilah, dkk (2007).

Hasil olah data untuk variabel pengalaman auditor diperoleh nilai probabilitas 0,047 dan diperoleh nilai koefisien regresi $=0,247$, maka dapat disimpulkan bahwa ada pengaruh positif dan signifikan antara pengalaman auditor terhadap audit judgement. Hal ini dapat diartikan, jika pengalaman auditor meningkat, maka audit judgement akan mengalami peningkatan.

Banyaknya pengalaman dalam bidang audit dapat membantu auditor dalam menyelesaikan tugas yang cenderung memiliki pola yang sama. Dengan demikian berarti hipotesis $\mathrm{H} 2$ terbukti dan konsisten dengan penelitian yang dilakukan oleh Kadek, dkk (2014).

Hasil olah data untuk variabel kompleksitas tugas diperoleh nilai probabilitasstatistik 0,005 dan diperoleh nilai koefisien regresi $=$ 1,234, maka dapat disimpulkan bahwa ada pengaruh yang positif dan signifikan antara kompleksitas tugas terhadap audit judgement. Hal ini dapat diartikan, jika kompleksitas tugas meningkat maka audit judgement akan mengalami peningkatan. Dengan demikian berarti hipotesis $\mathrm{H} 3$ tidak terbukti dan tidak konsisten dengan penelitian yang dilakukan oleh Ariyantini, dkk (2014), hal ini bisa disebabkan karena auditor sudah professional sehingga banyaknya tugas atau kejelasan tugas yang harus dikerjakan bukan sesuatu yang susah untuk dikerjakan dan bisa menghasilkan audit yang baik. Hasil penelitian ini didukung dengan penelitian yang dilakukan oleh Raiyani dan Suputra (2014).

Hasil olah data untuk variabel tekanan ketaatan diperoleh nilai probabilitas0,026 dan diperoleh nilai koefisien regresi $=-0,568$ maka dapat disimpulkan bahwa ada pengaruh yang negatif dan signifikan antara tekanan ketaatan terhadap audit judgement. Hal ini dapat diartikan, jika tekanan ketaatan menurun maka audit judgement akan mengalami peningkatan. Semakin tinggi tekanan yang dihadapi oleh auditor maka judgement yang diambil oleh auditor cenderung kurang tepat sehingga dapat mempengaruhi auditor dalam membuat suatu judgement. Dengan demikian berarti hipotesis $\mathrm{H} 4$ terbukti dan konsisten dengan penelitian yang dilakukan oleh jamilah, dkk (2007).

Hasil olah data untuk variabel kemampuan kerja auditor diperoleh nilai probabilitas 0,013 dan diperoleh nilai koefisien regresi $=1,522$ maka dapat disimpulkan bahwa ada pengaruh yang positif dan signifikan antara kemampuan kerja terhadap audit judgement. Hal ini dapat diartikan, jika kemampuan kerja meningkat maka audit judgement akan mengalami peningkatan. Adanya kemampuan seorang auditor dituntut untuk memiliki kemampuan untuk melakukan judgement yang akan diambil oleh auditor, sehingga keputusan yang diambil bisa menjadi keputusan yang terbaik. Dengan demikian berarti hipotesis H5 terbukti dan konsisten dengan penelitian yang dilakukan oleh Praditaningrum dan Januarti (2011).

Hasil olah data untuk variabel pengetahuan auditor diperoleh nilai probabilitas 0,000 dan diperoleh nilai koefisien regresi $=1,851$, maka dapat disimpulkan bahwa ada pengaruh yang positif dan signifikan antara pengetahuan auditor terhadap audit judgement. Hal ini dapat diartikan, jika pengetahuan auditor meningkat, maka audit judgement akan mengalami peningkatan. Tingkat pengetahuan yang dimiliki auditor merupakan hal yang sangat penting yang dapat mempengaruhi auditor dalam mengambil keputusan. Dengan 
demikian berarti hipotesis $\mathrm{H} 6$ terbukti dan konsisten dengan penelitian yang dilakukan oleh Fitriani dan Daljono (2012).

\section{PENUTUP}

\section{Kesimpulan}

Berdasarkan hasil penelitian yang telah dilakukan, maka dapat dibuat kesimpulan sebagaiberikut:

1. Gender tidak berpengaruh signifikan terhadap audit judgement.

2. Pengalaman Auditor berpengaruh positif terhadap audit judgement.

3. Kompleksitas Tugas berpengaruh positif terhadap audit judgement.

4. Tekanan Ketaatan berpengaruh negatif terhadap audit judgement.

5. Kemampuan Kerja berpengaruh positif terhadap audit judgement.

6. Pengetahuan Auditor berpengaruh positif terhadap audit judgement.

\section{Keterbatasan}

Peneliti menyadari bahwa hasil penelitian ini belum menghasilkan kesimpulan yang sempurna, hal ini karena masih terdapat beberapa keterbatasan diantaranya :

1. Sampel kurang representatif (hanya 35 sampel) sehingga hasil penelitian kurang dapat digeneralisasi.

2. Penelitian ini hanya meneliti variabel dependen audit judgement yang dijelaskan oleh variabel independen yaitu gender, pengalaman auditor, kompleksitas tugas, tekanan ketaatan, kemampuan kerja, dan pengetahuan auditor sebesar $62,4 \%$, tanpa meneliti $37,6 \%$ yang dijelaskan variabel di luar model.

\section{Saran}

Berdasarkan simpulan yang telah dikemukakan di atas, maka saran-saran yang diajukan adalah :

1. Sebaiknya pemimpin inspektorat memperhatikan pengalaman auditor, kompleksitas tugas, tekanan ketaatan, kemampuan kerja, dan pengetahuan auditor dalam mempertimbangkan kinerja auditor. Hal ini penting karena keenam faktor tersebut dapat mempengaruhi audit judgement dalam pemeriksaan laporan keuangan.

2. Bagi auditor, perlu ditingkatkannya profesionalisme kinerja, perkiraan waktu audit yang akan digunakan dan menambah pengalaman untuk menghindari peningkatan tingkat risiko deteksi dalam pemeriksaan laporan keuangan ataupun audit judgement.

3. Bagi peneliti selanjutnya diharapkan melakukan pengujian mengenai pengaruh gender terhadap audit judgement dengan menggunakan dasar Surat Al-Baqarah : 282 yang menyatakan bahwa nilai pria sebagai saksi 2 kali dibandingkan dengan wanita. Selain itu, sebaiknya menambah variabel independent misalnya fee, bonus, profesionalisme, dan lain-lain.

\section{DAFTAR PUSTAKA}

Ariyantini, Kadek Evi., Sujana, Edy., Darmawan, Nyoman Ari Surya. (20l4). "Pengaruh Pengalaman Auditor, Tekanan Ketaatan dan Kompleksitas Tugas Terhadap Audit Judgement". Jurnal Akuntansi Program SI, Vol 2 (I).

Bastian, Indra. (2007). Audit Sektor Publik. Jakarta: Salemba Empat.

Fitriani, Seni., dan Daljono. (20/2). "Pengaruh Tekanan Ketaatan, Kompleksitas Tugas, Pengetahuan dan Persepsi Etis terhadap Audit Judgement". Diponegoro Journal Of Accounting, Vol I (I) Hal. I-I 2.

Herawaty, Arleen, dan Susanto (2009). "Pengaruh Profesionalisme, Kemampuan Mendeteksi Kekeliruan, dan Etika Profesi Terhadap Pertimbangan Materialitas Akuntan Publik". Jurnal Akuntansi dan Keuangan, Vol II (I) Hal. I320.

Herliansyah, Yudhi, dan llyas. (2006). "Pengaruh Pengalaman Auditor Terhadap Penggunaan Bukti Tidak Relevan Dalam Auditor Judgement". Padang SNA IX.

Jamilah, Siti., Fanani, Zaenal., Chandrarin, Grahita. (2007). "Pengaruh Gender, Tekanan Ketaatan dan 
Kompleksitas Tugas Terhadap Audit Judgement”. Makassar: Simposium Nasional Akuntansi X.

Kushasyandita, RR, Sabrina., dan Januarti, Indira. (2012). "Pengaruh Pengalaman, Keahlian, Situasi Audit, Etika dan Gender terhadap Ketepatan Pemberian Opini Audit melalui Skeptisme Professional Auditor (Studi Kasus Pada KAP Big Four di Jakarta)". Banjarmasin: SNA XV.

Mardisar, Diani., dan Sari, Ria, N. (2007). "Pengaruh Akuntabilitas dan Pengetahuan terhadap Kualitas Hasil Kerja Auditor". Makassar: SNA X. AUEP-I I

Praditaningrum,A,S., dan Januarti, I. (20II). "Analisis Faktor-Faktor yang Berpengaruh terhadap Audit Judgement".

http://sna.akuntansi.unikal.ac.id/ diakses 27 Agustus 2014).

Raiyani, N, L, Kadek, Puput., dan Suputra, I, D, G, Dharma. (20l4). Pengaruh Kompetensi, Kompleksitas Tugas, dan Locus of Control terhadap Audit Judgement. E-jurnal Akuntansi Universitas Udayana, Vol 6 (3) Hal 429-438.

Robbins, Stephen, P., dan Judge, Timothy, A. (2007). Perilaku Organisasi. Jakarta: Salemba Empat.

Sukriah, Ika,. Akram,. Inapty, Biana, A,. (2009). "Pengaruh Pengalaman Kerja, Independensi, Obyektifitas, Integritas dan Kompetensi Terhadap Kualitas Hasil Pemeriksaan". Palembang: SNA XII. 